\title{
Brachyura (Crustacea, Decapoda) Associated to Schizoporella unicornis (Bryozoa, Gymnolaemata) in Ubatuba Bay (SP), Brazil
}

\author{
Fernando L. M. Mantelatto* and Marisa M. Souza-Carey \\ Departamento de Biologia, FFCLRP, Universidade de São Paulo, Av. Bandeirantes - 3900, CEP. 14040-901, \\ Ribeirão Preto (SP), Brasil, NEBECC (Group of Studies on Biology, Ecology and Culture of Crustaceans)
}

\begin{abstract}
This work characterizes the composition of Brachyura from Schizoporella unicornis. The samples were collected in 1995 at Itaguá Beach, Ubatuba (SP), at three month intervals, during all seasons from January to December. The Bryozoa colonies were obtained by snorkeling at a depth of five meters in daylight. A total of 323 specimens were collected from four families (Xanthidae, Portunidae, Majidae and Grapsidae). Pachygrapsus transversus, Hexapanopeus schimitti, and Menippe nodifrons occurred in all seasons. The highest and lowest number of individuals occurred during the spring and autumn, respectively. Xanthidae exhibited the highest density during the summer, autumn, and spring, while Grapsidae exhibited the highest density in winter. It was noted the presence of Charibdis hellerii, an portunid from Indo-Pacific ocean. The diversity of species obtained, in addition to an accentuated number of immature and ovigerous females specimens, suggested that Schizoporella colonies were a place of reproduction and development.
\end{abstract}

Key words: brachyuran, bryozoan, check list, crabs, Schyzoporella

\section{INTRODUCTION}

The high level of environmental adaptations exhibited by marine organisms is proportional to the high number of inter species associations. In many cases, the joining of some species can develop into a micro environment where the animals can find protection from predators, food, and a safe place for reproduction and the development of immature organisms (Mantelatto \& Souza-Carey, 1998).

According to Gordon (1972) bryozoans, also associated with hermit crabs, in general, have ecological importance and influence in the feeding and protection of other groups (Echinoidea, Asteroidea, Ophiuroidea, Polyplacophora), while competing for space with other organisms (bryozoans, ascidians, sponges, and tubicolous polychaetes).

It is known that, like other colonial formations, Schizoporella unicornis shelter a large and diversified fauna of invertebrates which are associated with them including decapod crustaceans. Many studies have concentrated on one or more species of decapods and their hosts (see Lindberg \& Stanton, 1988). However, more intensive studies of the species that compose this microhabitat need to be performed. Some research has been done in order to provide more information about these associations such as Lindberg (1980), Lindberg \& Frydenborg (1980) and Lindberg \& Stanton (1989).

\footnotetext{
* Author for correspondence
} 
The brachyuran crabs are the most commonly found animals in this association but there are no data on whether a Brachyura community exists in this biotope. However, there has been a few works in Brazil that reported the composition of this group in several habitats (Tommasi, 1967; Coelho \& Ramos-Porto, 1972; Abreu, 1980; Melo, 1985, 1986; Melo et al., 1989; Fransozo et al., 1992; Hebling et al., 1994; Mantelatto \& Corrêa, 1996; Mantelatto \& Souza-Carey,1998).

Here we provide the composition of Brachyura crabs associated with colonies of bryozoan $S$. unicornis, collected at Ubatuba Bay (SP), in order to increase the knowledge on the biodiversity of this group in this region to support future studies on resource relationships.

\section{MATERIAL AND METHODS}

The specimens were collected on Itaguá beach $\left(23^{\circ} 27^{\prime} 04^{\prime \prime} \mathrm{S}\right.$ and $\left.45^{\circ} 02^{\prime} 49^{\prime \prime} \mathrm{W}\right)$, Ubatuba, on the northern coast of São Paulo State. Our particular sampling site was the area around the columns underneath a pier in this area. The bryozoan colonies were obtained by two persons snorkeling at a depth between one and five meters in daylight for one hour. Four samples were collected at three-month intervals (to avoid disrupting the colony sites), during all seasons from January to December of 1995.

In each season, five samples of $S$. unicornis were obtained. For each sample, a 5-liter resealable plastic bag was placed quickly over an individual head, with the edges of the bag pushed through the sand beneath the head to dislodge it. The bag was then quickly sealed with the head and the animals within the head inside.

The samples were kept frozen until analysis. They were thawed at room temperature and drained manually in the laboratory. The animals were extracted by breaking the colonies with a pair of pliers.
The bryozoan was identified by Dr. Paulo S. Young from National Museum of Federal University of Rio de Janeiro. The crabs were preserved in a 70\% alcohol solution and identified by Dr. Gustavo Augusto S. de Melo from Zoology Museum of University of São Paulo.

All the animals were measured under a stereomicroscope optic with a camera lucida. For the larger crabs, a caliper rule $(0,01 \mathrm{~mm})$ was used. The measurement was based upon the largest width of the carapace not including the lateral spines.

\section{RESULTS}

A total of 323 specimens were collected from $7033,25 \mathrm{~g}$ (dry weight) of $S$. unicornis during this study. The animals found belonged to four families (Table 1): Xanthidae, Portunidae, Majidae and Grapsidae. Xanthidae and Portunidae were the dominant families in the colonies, which were represented by a total of 14 species which were able to be identified. Three species were found in all seasons: Pachygrapsus transversus, Hexapanopeus schmitti and Menippe nodifrons. Also, 84 animals belonging to the Xanthidae were found, whose species were not able to be identified. The highest species diversity and abundance of individuals were registered in summer and spring, respectively. The family Xanthidae registered the highest number of animals.

The average size of males, females and ovigerous females of the most abundant species is presented on Table 2 .

The geographical distribution of the portunid Charybdis hellerii was amplified. This is the third register of its occurrence in Brazil, and the second occurrence in the north littoral of São Paulo State. Whereas some species were only captured occasionally, represented by 1-3 specimens. 
Table 1. Number of individuals captured in S. unicornis on Ubatuba Bay (SP) during 1995.

\begin{tabular}{ccccccc}
\hline Family & Species & Summer & Autumn & Winter & Spring & TOTAL \\
& Pachygrapsus transversus & 1 & 2 & 55 & 17 & 75 \\
\hline MAJIDAE & Apiomithrax violaceus & - & - & - & 2 & 2 \\
& Epialtus sp. & - & 1 & - & - & 1 \\
& Macrocoeloma trispinosum & - & - & 1 & - & 1 \\
& Mithraculus forceps & 2 & 1 & - & - & 3 \\
& Mithrax hispidus & 1 & - & 1 & - & 2 \\
& Microphrys bicornutus & 1 & - & - & - & 1 \\
& Pelia rotunda & 1 & - & 1 & 1 & 3 \\
& Stenorhynchus seticornis & 1 & 1 & - & 1 & 3 \\
\hline PORTUNIDAE & Charybdis hellerii & - & 1 & 1 & 5 & 7 \\
& Portunus ordwayi & - & - & - & 4 & 4 \\
\hline XANTHIDAE & Eurypanopeus abbreviatus & 1 & - & - & - & 1 \\
& Eurytium limosum & 1 & - & - & - & 1 \\
& Hexapanopeus paulensis & 17 & 5 & 1 & - & 23 \\
& Hexapanopeus schmitti & 35 & 2 & 1 & 1 & 39 \\
& Menippe nodifrons & 6 & 10 & 5 & 5 & 26 \\
& Pilumnus diomedeae & 4 & 6 & - & 9 & 19 \\
& Pilumnus reticulatus & 10 & 4 & - & 4 & 18 \\
& Pilumnus sp. & - & 2 & 2 & 6 & 10 \\
& Xanthidae sp. & 1 & 16 & 13 & 54 & 84 \\
\hline TOTAL & 82 & 51 & 81 & 109 & 323 \\
\hline
\end{tabular}

Table 2. Size of the crabs collected in S. unicornis on Ubatuba Bay (SP) during 1995 (x = average; $\mathrm{sd}=$ standard deviation $) *$.

\begin{tabular}{|c|c|c|c|c|}
\hline \multirow[t]{2}{*}{ Family } & \multirow[t]{2}{*}{ Species } & \multicolumn{3}{|c|}{$\begin{array}{l}\text { Maximum - Minimum } \\
(\mathrm{x} \pm \mathrm{sd}) \\
\end{array}$} \\
\hline & & Males & Females & Ovigerous females \\
\hline GRAPSIDAE & Pachygrapsus transversus & $\begin{array}{c}7.0-2.2 \\
(4.6 \pm 2.4) \\
\end{array}$ & $\begin{array}{r}7.6-2.9 \\
(5.4 \pm 2.4) \\
\end{array}$ & - \\
\hline \multirow[t]{2}{*}{ PORTUNIDAE } & Charybdis hellerii & $\begin{array}{c}26.6-10.05 \\
(18.4 \pm 8.3)\end{array}$ & $\begin{array}{c}20.3-5.2 \\
(17.8 \pm 2.6)\end{array}$ & - \\
\hline & Portunus ordwayi & $\begin{array}{c}5.9-2.5 \\
(4.2 \pm 1.7) \\
\end{array}$ & $\begin{array}{c}2.5-2.3 \\
(2.4 \pm 0.1) \\
\end{array}$ & - \\
\hline \multirow[t]{7}{*}{ XANTHIDAE } & Hexapanopeus paulensis & $\begin{array}{c}3.5-2.6 \\
(3.5 \pm 0.5)\end{array}$ & $\begin{array}{c}4.9-2.7 \\
(3.8 \pm 1.1)\end{array}$ & - \\
\hline & Hexapanopeus schmitti & $\begin{array}{c}1.5-1.9 \\
(3.7 \pm 1.8)\end{array}$ & $\begin{array}{c}6.2-2.6 \\
(4.4 \pm 1.8)\end{array}$ & $\begin{array}{c}4.2-1.8 \\
(3.0 \pm 1.2)\end{array}$ \\
\hline & Menippe nodifrons & $\begin{array}{c}8.5-1.2 \\
(4.9 \pm 3.7)\end{array}$ & $\begin{array}{c}7.0-5.3 \\
(6.2 \pm 0.9)\end{array}$ & - \\
\hline & Pilumnus diomedeae & $\begin{array}{c}4.0-2.2 \\
(3.1 \pm 0.9)\end{array}$ & $\begin{array}{c}7.1-2.6 \\
(4.9 \pm 2.3)\end{array}$ & $\begin{array}{l}4.1-4.1 \\
\quad(4.1)\end{array}$ \\
\hline & Pilumnus reticulatus & $\begin{array}{c}5.0-3.6 \\
(4.3 \pm 0.8)\end{array}$ & $\begin{array}{c}6.8-3.9 \\
(5.4 \pm 1.5)\end{array}$ & - \\
\hline & Pilumnus sp. & $\begin{array}{c}2.4-2.2 \\
(2.2 \pm 0.5)\end{array}$ & $\begin{array}{c}5.0-4.4 \\
(4.7 \pm 0.3)\end{array}$ & - \\
\hline & Xanthidae sp. & $\begin{array}{c}5.1-1.3 \\
(3.2 \pm 1.9)\end{array}$ & $\begin{array}{c}6.9-2.0 \\
(4.5 \pm 2.5)\end{array}$ & $\begin{array}{c}4.0-3.7 \\
(3.9 \pm 0.2)\end{array}$ \\
\hline
\end{tabular}

* The absence of data to many species is due to none or only occurrence of specimen in the samples 


\section{DISCUSSION}

If we consider the proportion of $S$. unicornis present in relation to other microhabitats from Ubatuba Bay occupied by the crabs (i.e., fital areas, poriferan, cnidarian and ascidian colonies, sea anemones, among others), the present study revealed that $S$. unicornis heads provided shelter for a great diversity of species and constituted a resource for brachyuran crabs. In the same period, another study was realized about the composition of Brachyura living in Sargassum cymosum algae on the same beach (Mantelatto \& Corrêa, 1996). Although this algae constituted a much more available resource in this area, the diversity of species and the number of individuals were lower than that documented to $S$. unicornis colonies.

Even though just one occurrence of a new species $(C$. hellerii) was documented, the most important focal point in this study was the high number of small-sized specimens (immature) and ovigerous females present in S. unicornis colonies, principally the Xanthidae family. The diversity of the Brachyura might be a result of the interaction between the characteristics of the species (e.g. size, life cycle, reproduction strategies) in association with a lack of living space to such a degree that immigration of rare species would only occur with an increase in the abundance of drift colonies. On the other hand, according to Lindberg (1980) and Lindberg \& Frydenborg (1980), the head size and architecture of colonies could determine the primary resource value by crabs because the mobility, refuge from predation, critical life cycle phases and positive correlation between crab size and head size.

The species of the Xanthidae family which frequently occurred in $S$. unicornis, corroborated the hypothesis that many species of this family presented a specific behavior during their life cycles in bryozoan colonies, e.g. Hexapanopeus schimitti and Pilumnus sayi studied by Morgado (1980) and Lindberg \& Stanton (1988), respectively.

In the Grapsidae family, P. transversus revealed

a high density of young individuals corroborating the idea about this species' association with others colonies to minimize predation during the initial phases of the life cycle, already demonstrated by $P$. transversus megalopa in relation to the polychaete Phragmatopoma lapidosa studied by Flores (1996).

The portunids $P$. ordwayi and $C$. hellerii, were considered an accidental occurrence. The latter one originates from the Indo-Pacific ocean, with a population dynamic unknown in this region. The Majidae species, demonstrates the characteristics of a visiting species in bryzoan colonies because of its high diversity and heterogeneous frequency of species within this community. Therefor, this species cannot be regarded as a permanent member of this biotope.

The crab community living in bryozoan $S$. unicornis is a good example of small crustaceans that are noted for their welldeveloped habitat, but are unstudied in terms of the processes and mechanisms that facilitate this phenomenon, which probably occurs because of the size, shape and arrangement of spatial and structural components of the habitat associated with food resources and defense of resources in social organization. Similar pattern was noted to crustaceans associated with sand reefs $P$. lapidosa (Pinheiro et al., 1997).

Observations made over the last ten years have revealed the expansion of the tourist industry in the Ubatuba region, which would likely have a detrimental effect on marine populations (Mantelatto \& Souza-Carey, 1998). This fact combined with the lack of studies available in the literature, suggests an urgent need of studies of brachyuran crabs living within microhabitats in this region. 


\section{ACKNOWLEDGMENTS}

We gratefully acknowledge the members of the NEBECC group for help during the collections and with animal screening in the laboratory. Taxonomic assistance was provided by Dr. Gustavo A. S. de Melo (Zoology Museum of University of São Paulo). Special thanks are due to Drs. Ricardo Macedo Corrêa e Castro and Wagner E. Paiva Avelar for criticism, who also helped us to improve the manuscript. We also wish to thank John C. Carey for the English review.

\section{RESUMO}

Este trabalho caracterizou a composição dos braquiúros em Schizoporella unicornis. As amostras foram coletadas na Praia do Itaguá, Ubatuba (SP), em intervalos de três meses, durante as estações climáticas de Janeiro a Dezembro/1995. As colônias de briozoários foram obtidas por mergulho livre, coletadas pela manhã. Um total de 323 espécimes foram coletados dentro de quatro famílias (Xanthidae, Portunidae, Majidae e Grapsidae). Pachygrapsus transversus, Hexapanopeus schimitti e Menippe nodifrons ocorreram em todas as estações. O maior e o menor número de indivíduos foram registrados na primavera e no outono, respectivamente. Xanthidae exibiu maior densidade no verão, outono e primavera, enquanto Grapsidae foi no inverno. Registrou-se a ocorrência de Charibdis hellerii, espécie originária do Indo-Pacífico. A diversidade de espécies obtida, juntamente com o acentuado número de indivíduos imaturos e fêmeas ovígeras, constituem indícios de que colônias de Schizoporella constituem um local de reprodução e desenvolvimento para estes crustáceos.

\section{REFERENCES}

Abreu, J. (1980), Distribuição e ecologia dos Decapoda numa área estuarina de Ubatuba, SP. Bolm. Inst. Oceanogr., 29(2), 1-3.

Coelho, P.A.; Ramos, M.A.A. (1972), Constituição e a distribuição da fauna de decápodos do litoral leste da América do Sul entre as Latitudes de $5^{\circ} \mathrm{N}$ e $39^{\circ} \mathrm{S}$. Trab. Oceanogr. Univ. Fed. Pernambuco, 13, 133-236.

Flores, A.A.V. (1996), Biologia de Pachygrapsus transversus (Gibbes, 1850) (Crustacea, Brachyura, Grapsidae) na região de Ubatuba, SP. Bachelor Thesis, Instituto de Biociências, Paulista State University, Botucatu, SP, Brazil, 143 pp.

Fransozo, A.; Negreiros-Fransozo, M.L.; Mantelatto, F.L.M.; Pinheiro, M.A.A.; Santos, S. (1992), Composição e distribuição dos Brachyura (Crustacea, Decapoda) do sublitoral não consolidado na Enseada da Fortaleza, Ubatuba (SP). Rev. Brasil. Biol., 52(4), 667-675.

Gordon, D.P. (1972), Biological relationships of an Intertidal Bryozoan population. J. Nat. Hist., 6, 503-514.

Hebling, N.J.; Mantelatto, F.L.M.; NegreirosFransozo, M.L.; Fransozo, A. (1994), Levantamento e distribuição de braquiúros e anomuros (Crustacea, Decapoda) dos sedimentos sublitorais da região da Ilha Anchieta, Ubatuba (SP). B. Inst. Pesca, 21(único), 1-9.

Lindberg, W.J. (1980), Patterns of resource use within a population of xanthid crabs occupying bryozoan colonies. Oecologia, 46, 338-342.

Lindberg, W.J.; Frydenborg, R.B. (1980), Resource centered agonism of Pilumnus sayi (Brachyura, Xanthidae), an association of the bryozoan Schyzoporella pungens. Behaviour, 75, 235-250.

Lindberg, W.J.; Stanton, G.R. (1988), Bryozoan-associated decapod crustaceans: community patterns and a case of cleaning symbiosis between a shrimp and crab. Bull. mar. Sci., 42(3), 411-423.

Lindberg, W.J.; Stanton, G.R. (1989), Resource quality, dispersion and mating prospects for 
crabs occupying bryozoan colonies. $J$. exp. mar. Biol. Ecol., 128, 257-282.

Mantelatto, F.L.M.; Corrêa, E.K. (1996), Composition and seasonal variations of the brachyuran crabs (Crustacea, Decapoda) living on Sargassum cymosum in Ubatuba region, São Paulo, Brazil. Bioikos, 910(1/2), 22-31.

Mantelatto F.L.M.; Souza-Carey, M.M. (1998), Caranguejos anomuros (Crustacea, Decapoda) associados à Schizoporella unicornis (Bryozoa, Gymnolaemata) em Ubatuba (SP), Brasil. Anais IV Simpósio de Ecossistemas Brasileiros, ACIESP, 2(104), 200-207.

Melo, G.A.S. (1996), Manual de identificação dos Brachyura (caranguejos e siris) do litoral brasileiro. Editora Plêiade/FAPESP, São Paulo, Brasil,, 604 pp.

Melo, G.A.S. (1985), Taxonomia e padrões distribucionais ecológicos dos Brachyura (Crustacea, Decapoda) do litoral sudeste do Brasil. Doctoral Thesis, University of São Paulo, MZUSP, São Paulo, Brazil, 215 pp.
Melo, G.A.S.; Veloso, V.G.; Oliveira, M.C. (1989), A fauna de Brachyura (Crustacea, Decapoda) do litoral do Estado do Paraná. Lista preliminar. Nerítica, 4 (1/1), 1-31.

Morgado, E.H. (1980), A endofauna de Schyzoporella unicornis (Johnston, 1847) (Bryozoa), no litoral norte do Estado de São Paulo. Master Thesis, State University of Campinas, Campinas, SP, Brazil, 110 pp.

Pinheiro, M.A.A.; G. Bertini; L.C. FernandezGóes \& Fransozo A. (1997), Decapod crustaceans associated to sand reefs of Phragmatopoma lapidosa Kinberg, 1867 (Polychaeta, Sabellariidae) at Praia Grande, Ubatuba, SP, Brazil. Nauplius, 5(2), 77-83.

Tommasi, L.R. (1967), Observações preliminares sobre a fauna bentônica de sedimentos moles da baía de Santos e regiões vizinhas. Bolm. Inst. oceanogr., 16 (1), 43-65. 